\title{
IMPROVING OILS STABILITY DURING DEEP-FAT FRYING USING NATURAL ANTIOXIDANTS EXTRACTED FROM AGRO- INDUSTRIAL BY-PRODUCTS
}

\author{
Sahar R. Abd El-Hady ${ }^{(1)}$, y.y. Shehab ${ }^{(2)}$, Awatif I. Ismail ${ }^{(2)}$ \\ and M.R. Nour El-Deen ${ }^{(1)}$ \\ ${ }^{(1)}$ Food Sci. and Technology Dept., Fac. of Argic., Kafrelsheikh Univ., Kafrelsheikh, Egypt \\ (2) Food Tech. Res. Inst., Agric. Res. Center, Giza, Egypt .
}

Received: Nov. 12,2018

Accepted: Dec. 30,2018

\begin{abstract}
The present study was carried out to evalute the possibility of extraction of some natural antioxidative (phenolic compounds) from agro-industrial by-products (mango seed kernel, mango peel, onion skin and black rice bran). The extracted phenolic compounds were tested as natural antioxidants using mixure of refined Sunflower $75 \%$ and soybean $25 \%$ oils after deep frying $\left(170-180^{\circ} \mathrm{C}\right)$ of potato for 25 hours compare with synthetic antioxidants; Tetra butyled hydroxyl quinone (TBHQ). The results indicated that methanolic extract gave the highest extract yield compared to the other solvent. Methanol exhibited the highest extraction ability for phenolic compound $(6.54,5.40,5.10$ and $6.80 \mathrm{mg} / \mathrm{gdw}$ ), for mango seed kernel, mango peel, onion skin and black rice bran extracts, respectively and also showed the strongest antioxidant activity of black rice bran extract activity owing to its high content of phenolic compounds. HPLC analysis for the total polyphenols extracted from agro-industrial by-products indicated Ferulic, $p$ coumaric and Caffeic acids were the major phenolic compounds presented and identified in black rice bran (164.3, 32.1, and $25.4 \mathrm{mg} / 100 \mathrm{~g}$, respectively); while Salicylic, Chtechin and Protocatechuic acids were the major phenolic compounds presented and identified in Mango seed kernel (60.7, 51.7 and $46.1 \mathrm{mg} / 100 \mathrm{~g}$ respectively). peroxide value of blend oils without additives (control) was increased significantly $(P \leq 0.05)$ after 5 days of storage at $60^{\circ} \mathrm{C}$ meanwhile slowed increase was detected in samples with $200 \mathrm{ppm}$ TBHQ and $400 \mathrm{ppm}$ phenolic compounds extracted from agro-industrial by-products . Peroxide and TBA values of the frying blend oils increased significantly $(P \leq 0.05)$ with increasing frying time. Black rice bran extract was more effective as antioxidant than those of the other studied agro-industrial by-products at 400 ppm and TBHQ at 200 ppm.
\end{abstract}

Key words: Mango seed kernel, mango peel, onion skin, black rice bran, phenolic compounds; antioxidant activity, oxidative stability.

\section{INTRODUCTION}

Deep frying is widely used for the preparation of many types of foods. The high temperatures reached during food frying lead to a complex series of reactions that resulted in hydrolysis, oxidation and polymerization of oil. (Gertz et al., 2000). Lipid oxidation is the main deterioration process that occurs during thermal processing of vegetable oils containing poly unsaturated lipid molecules. Additionally, certain oxidation products are potentially toxic at relatively low concentrations (EI Anany, 2007). The addition of antioxidants is considered as one of the methods of increasing shelf life of lipids and lipid-containing foods. Synthetic antioxidant, such as butylated hydroxyl anisole (BHA) and butylated hydroxyl - toluene (BHT), have restricted use in foods as these synthetic antioxidants are suspected to be carcinogenic (Hou 2003 and Jayaprakasha et al., 2001). Due to these safety concerns, there is an increasing trend among food scientists to replace 
these synthetic antioxidants with natural ones, which, in general, are supposed to be safer (Yanishlieva and Marinova, 2001). Antioxidants (natural and synthetic) play a significant role in retarding lipid oxidation reactions in food products. The main classes of natural antioxidant compounds in nature are flavonoids and phenolic acids in free or complexes forms. These compounds have been identified and quantified in several fruits and vegetables, and show a high correlation with antioxidant activity (Einbond et al., 2004). Dried mango peel and kernel products can improve the nutritional, functional and sensory properties, and oxidative stability of oil/oil rich product (Abdalla et al., 2007b). Mango peel is rich in pectin, cellulose, hemicellulose, lipids, protein, polyphenols and carotenoids with excellent antioxidant and functional properties (Ajila et al., 2007). Mango peel and kernel contain various classes of polyphenols, carotenoids, and vitamins with different health-promoting properties, mainly antioxidant activity (Manthey and Perkins-Veazie, 2009). Mango kernels are rich sources of gallic acid, ellagic acid, ferulic acid, cinnamic acids, tanins, vanillin, coumarin, and mangiferrin, all having potential to act as a source of natural antioxidants (Abdalla et al., 2007a).

In recent years, the consumption of onion has increased due to its flavor and health benefits. These beneficial properties seem to strongly relate to the high content of sulfur compounds and flavonoids. Because of their activity as antioxidants and anticarcinogens, their effects on lipid metabolism and the cardiovascular system, and their antibiotic effects were put under investigation (Griffiths et al., 2002). The flavonoids present in the onion consist of anthocyanins (cyanidin and peonin) and mainly flavonols (quercetin, kaempferol, isorhamnetin, and their glycosides). The onion skin has a high content of free and glycosidically bonded quercetin (2-10\% $\mathrm{w} / \mathrm{w})$ and oxidized quercetin derivatives such as minor flavonols and phenolic compounds (Hala, S. Sayed, et al., 2014). Rice, being one of the most produced and consumed cereals in the world, has an important role in the relation between the diet and health. Several compounds with antioxidant activity have been identified in rice, including phenolic compounds, tocopherols, tocotrienols and $\boldsymbol{\gamma}$-oryzanol (Iqbal et al., 2005). The phenolic compounds are mainly associated with the pericarp in rice, hence, the milling process reduces the concentration of these compounds in the grain. Besides, grains with darker pericarp colour, such as red and black rice, contain higher amounts of polyphenols (Walter and Marchesan, 2011). In addition, the concentration of total phenolics in the grain has been positively associated with the antioxidant activity, with potential beneficial effects on health, such as reduction of oxidative stress, aid in the prevention of cancer, in the blood lipids control and related diseases, which may help in the prevention of cardiovascular problems, and in the prevention of the complications of diabetes (Yawadio et al., 2007). The present study was under taken to evaluate the efficiency of natural antioxidants extracted from agroindustrial by-products (mango seed kernel, mango peel, onion skin and black rice bran) as a new sources of natural antioxidants during frying process of oil Blends in a comparison with TBHQ as synthetic antioxidant.

\section{MATERIALS AND METHODS}

\section{Materials:}

Market-ripe mangoes (Magnifera indica L.) zebda variety and red onion (Allium cepa L.) were purchased from local market, Kafer El-Sheikh , Egypt , Season 2016.

Black rice bran (Oryza sativa L.) was obtained from the Rice Research and 
Training Center (RRTC), Sakha, Kafer EISheikh , Egypt, Season 2016 and stored in deep freezing at $-20^{\circ} \mathrm{C}$ until further use. Commercial antioxidant; Tetra butyled hydroxyl quinone (TBHQ), 1,1-diphenyl -2 -picrylhydrazyl (DPPH), Folin- ciocalteau reagents and solvents were purchased from Sigma-Aldrich Co. (St. Louis, Mo., U.S.A.) and Blend it oils (mixed of refined Sunflower $75 \%$ and soybean $25 \%$ oils) antioxidant free were obtained from Tanta Company for Oils and Soap, Tanta, Egypt, (2016).

\section{Methods:}

Preparation of samples:

A-Preparation of mango peels and kernels:

Fruits were sorted for maturity and defects, followed by well washing. Peel and kernel stones were removed manually using stainless steel knives. The stones were opened to get kernels. Mango peel were cut into thin strips whereas the kernels were cut crosssection wise into thin thick slices. Mango peel and kernel pieces were spread in single layer and dried at $50^{\circ} \mathrm{C}$ and finely ground into powdery form .

\section{B-Preparation of onion skin powder (OSP):}

Onion skin powder (OSP) was prepared according to the method described by Gawlik-Dziki et al. (2013) as follows: the dried onion skin was separated and washed twice with deionized water and dried in an oven at $50^{\circ} \mathrm{C}$. Once dried, the samples were powdered using a laboratory mill and then sieved (60 mesh). and stored in deep freeze at $-20^{\circ} \mathrm{C}$ until further use.

\section{Extraction of natural antioxidants from agro-industrial by-products:}

The prepared ground materials $(\mathbf{1 0} \mathrm{g})$ of each sample were soaked in $100 \mathrm{ml}$ of each solvent (Ethanol, Acetone, Ethyl acetate and Methanol) over night in a shaker at room temperature according to
Mohdaly et al. (2010). The extracts were filtrated through Whatman No.1 filter paper. The residues were re-extracted three time under the same conditions. The combined filtrates were evaporated under vacuum in a rotary evaporator below $40^{\circ} \mathrm{C}$. The extracts obtained after evaporation of organic solvents were weighted to determine the extract yield and stored at $-20^{\circ} \mathrm{C}$ until further analysis.

Gross chemical composition of agro-industrial by-products:

Moisture, Crude fat, Crude protein, and ash content were determined according to the methods of A.O.A.C. (2005). Total carbohydrates were determined by difference.

\section{Determination of total phenolic compounds:}

Total phenolic compounds of the extracts were determined spectrophotometrically using Folinciocalteau reagent according to the method described by Bonoli et al. (2004) and used to estimate the phenolics-acid content using a standard curve prepared using tannic acid.

Determination of DPPH radical scavenging capacity:

The 1,1-diphenyl - 2- picrylhydrazyl (DPPH) assay was based on the method of Lee et al. (2003) .

\section{Identification of phenolic compounds by HPLC: \\ Phenolic compounds of agro- industrial by-products samples were extracted according to the method outlined by Evangelisti et al. (1997).}

\section{Antioxidant activity testing:}

Extracted phenolic compounds from agro-industrial by-products samples were tested as Antioxidant by the determination of peroxide value (POV) during incubation of blend oil at $60^{\circ} \mathrm{C}$ for 7 days as described by Matthous, (2002). 


\section{Frying performance:}

Frying oil blend $3 \mathbf{~ k g}$ (sunflower 75\% and soybean $25 \%$ oils) were heated in a domestic fryer (Model 7122 A, Tefal Super 500 deluxe, France) to $185+5^{\circ} \mathrm{C}$. Potato tubers were first washed with tap water then manually peeled, cut into $5.0 \mathrm{x}$ $0.7 \times 0.7 \mathrm{~cm}$ pieces using mechanical cutter (type chef, La Minerva, Italy) and submerged in tap water until frying. After draining off excess water, $200 \mathrm{~g}$ of them were placed in a wire basket and deep fried in the tested Blend oils as follows:

1- Blend Oil without any antioxidant treatment.

2- 2- Blend Oil treating with (200 ppm) Tetra butyled hydroxyl quinone (TBHQ).

3- Blend Oil treating with (400 ppm) of Methanolic extract from mango seed kernel.

4- Blend Oil treating with (400 ppm) of Methanolic extract from mango peel.

5- Blend Oil treating with (400 ppm) of Methanolic extract from onion skin.

6- Blend Oil treating with (400 ppm) of Methanolic extract from black rice bran. As described by Mostafa, (2013) with some modified. The frying process was daily repeated for five hours. The heating frying cycle was continued for five days. At the end of each frying period, the oil was filtered through muslin to remove the remaining fried particles, allowed to cool overnight at room temperature. Two hundred $\mathrm{ml}$ of the filtered oils were taken and preserved in dark glass bottles with stoppers in a refrigerator until analyzed.

Peroxide value (PV): was determined by potassium iodide method according to Leonard et al. (1987).

lodine value: lodine value was determined via titration by sodium

Table (1): Gross chemical composition of agro-industrial by-products ( $/ 100 \mathrm{~g}$ on dry thiosulfate according to the method described in A.O.A.C, (2005).

Thiobarbituric acid (TBA): values were determined according to Sidwell et al. (1990). The concentration of malonaldehyde in oil samples were calculated from standard curve. Absorbance was read at $532 \mathrm{~nm}$ against distilled water.

\section{Statistical analysis:}

Most of the received data were analyzed statistically using the analysis of variance and the means were further tested using the least significant difference test (LSD) as outlined by Steell and Torrie (1980).

\section{RESULTS AND DISCUSSION}

Gross chemical composition of agroindustrial by-products $(\mathrm{g} / 100 \mathrm{~g}$ dry weight).

The chemical composition of agroindustrial by-products (mango seed kernel, mango peel, onion skin and black rice bran) were determined and the results are recorded in Table (1). The moisture content of agro-industrial byproducts were ranged from (5.24 to 12.66\%). However, black rice bran contain the highest content of crud protein which was $(16.11 \%)$ followed by mango seed kernel which recorded (7.33\%) while the lowest value of crud protein was $(2.67 \%)$ for onion skin.

Apparent also from the same table that, Crude Fat contents were $9.89 \%$ in Mango seed kernel, $1.48 \%$ in Mango peel, $1.03 \%$ in Onion skin and $16.95 \%$ in black rice bran. Furthermore, agro-industrial by-products contain 1.89 to $7.71 \%$ ash content, and 59.23 to $90.20 \%$ total carbohydrate. These results are in line with Ajila et al. (2010); Hala, S. Sayed et al. (2014); Nordin et al. (2014); El-Faham, et al. (2016); El-hassaneen, et al. (2016); Elizabeth et al. (2017) and Gumte, et al., (2018).

\footnotetext{
weight basis).
} 
Improving oils stability during deep-fat frying using natural antioxidants

\begin{tabular}{|l|c|c|c|c|c|}
\hline Samples & Moisture & Crude protein & Crude Fat & Ash & carbohydrates \\
\hline $\begin{array}{l}\text { Mango seed } \\
\text { kernel }\end{array}$ & $5.94^{\mathrm{c}}$ & $7.33^{\mathrm{b}}$ & $9.89^{\mathrm{b}}$ & $1.89^{\mathrm{d}}$ & $80.89^{\mathrm{c}}$ \\
\hline Mango peel & $12.66^{\mathrm{a}}$ & $5.50^{\mathrm{c}}$ & $1.48^{\mathrm{c}}$ & $3.15^{\mathrm{c}}$ & $89.87^{\mathrm{b}}$ \\
\hline Onion skin & $5.24^{\mathrm{d}}$ & $2.67^{\mathrm{d}}$ & $1.03^{\mathrm{d}}$ & $6.10^{\mathrm{b}}$ & $90.20^{\mathrm{a}}$ \\
\hline black rice bran & $8.56^{\mathrm{b}}$ & $16.11^{\mathrm{a}}$ & $16.95^{\mathrm{a}}$ & $7.71^{\mathrm{a}}$ & $59.23^{\mathrm{d}}$ \\
\hline LSD & $* *$ & $* *$ & $* *$ & $* *$ & $*$ \\
\hline
\end{tabular}

* Each value is an average of three determinations.

+ Values followed by the same letter in Colum are not significantly different at $P \leq 0.05$.

*= Significant; **= high Significant; NS= No Significant.

Effect of solvent type on the extraction yield of agro -industrial by-products (Yield g $/ 100 \mathrm{~g}$ of dry weight).

Choice of solvent plays a vital role in the extraction of phytochemicals. Earlier studies reported the use of polar solvents for effective extraction of phenolic compounds (QD et al., 2014). Antioxidant compound extracted from agro-industrial by-products (mango seed kernel, mango peel, onion skin and black rice bran) using different solvents (ethanol, acetone, ethyl acetate and methanol) were showed in Table (2). It was observed that methanol extracts of black rice bran had the highest amount of extract yields $(23.89 \mathrm{~g} / 100 \mathrm{~g})$, while the lowest extract yields recorded for onion skin (7.30 g / 100g) with aceton. Furthermore, The extraction yield increase in order: Acetone < Ethyl acetate $<$ ethanol < methanol.

These results are similar with that obtained by Sultana et al. (2007) who reported that, rice bran had the highest yield of antioxidant than rice hull. Furthermore, The polarity of the solvent and of the different phenolic compounds affect extraction efficiency and the activity of the obtained extracts (Gonzalez and Gonzalez 2010). Generaly, highly hydroxylated aglycone forms of phenolic compounds are soluble in alcohols such as methanol or ethanol and their mixtures with water (Lafka et al.,

Table (2): Effect of using different solvents on yield extracted from agro -industrial byproducts ( $\mathrm{g} / 100 \mathrm{~g}$ of dry weight).

\begin{tabular}{|c|c|c|c|c|}
\hline \multirow{2}{*}{$\begin{array}{c}\text { Extraction } \\
\text { solvent }\end{array}$} & \multicolumn{3}{|c|}{ (extracted Yields g/100 g of dry weight) } \\
\cline { 2 - 5 } & $\begin{array}{c}\text { mango seed } \\
\text { kernel }\end{array}$ & mango peel & Onion skin & black rice bran \\
\hline Ethanol & $20.75^{\mathrm{b}}$ & $16.84^{\mathrm{a}}$ & $10.73^{\mathrm{b}}$ & $22.82^{\mathrm{b}}$ \\
\hline Acetone & $16.45^{\mathrm{d}}$ & $7.78^{\mathrm{c}}$ & $7.30^{\mathrm{d}}$ & $16.82^{\mathrm{d}}$ \\
\hline Ethyl acetate & $18.74^{\mathrm{c}}$ & $9.98^{\mathrm{b}}$ & $8.65^{\mathrm{c}}$ & $20.86^{\mathrm{c}}$ \\
\hline Methanol & $22.65^{\mathrm{a}}$ & $16.90^{\mathrm{a}}$ & $13.40^{\mathrm{a}}$ & $23.89^{\mathrm{a}}$ \\
\hline LSD & $* *$ & $* *$ & $* *$ & $* *$ \\
\hline
\end{tabular}

* Each value is an average of three determinations.

+ Values followed by the same letter in Colum are not significantly different at $P \leq 0.05$.

*= Significant; **= high Significant; NS= No Significant. 
Effect of solvents type on total polyphenol extracted from agroindustrial by-products.

Total polyphenols extracted from (mango seed kernel, mango peel, onion skin and black rice bran) are given in Table (3). The data indicate that methanol was the best solvent for extracting polyphenols from the studied agroindustrial by-products. High, amounts of extracted polyphenolic compounds by methanol from black rice bran, mango seed kernel, mango peel and onion skin, were $6.80,6.54,5.40$ and $5.10 \mathrm{mg}$ tannic $I$ g dw, respectively, comparing with other solvents. These results are similar with that obtained by Su et al. (2007) They revealed that, methanol and ethanol were better $(P<0.05)$ than the ethyl acetate and acetone for extracting phenolic compounds owing to their higher polarity and good solubility for phenolic components from plant materials. On the other hand, the data in the same table showed that, black rice bran contained highest amounts of polyphenolic compounds with all using solvents comparing with other agro-industrial byproducts. These results are agreement with the results obtained by Kim et al., (2010); Araba et al. (2011); Abdel et al.
(2012); Hala, S. Sayed et al. (2014); Abbasi et al. (2015); Pitchaporn, and Sirithon, (2016); Viera, et al. (2017); Azza M. Abdel-Aty, et al. (2018) and Salem et al. (2018).

Antioxidant activity of methanol extracts from agro-industrial byproducts.

The free redical scavenging of the extracts of agro-industrial by-products were evaluated using the DPPH method and the results were presented in Table (4) The results showed that, antioxidant activity of TBHQ was higher than all extracts at different level. In addition, The DPPH radical scavenging of mango seed kernel, mango peel, onion skin, black rice bran and TBHQ at concentration of 400 ppm were 80.30, $78.10,78.19,82.90$ and $97.20 \%$. The varied radical scavenging activity of the extracts depended on the amount of total phenolic in each agro-industrial byproducts This difference might be due to the interspecies variation. These findings are in close agreement with previous findings of Ajila et al. (2010); Yao et al. (2010); Hala, S. Sayed, et al. (2014); ElFaham, et al. (2016); Pitchaporn, and Sirithon

(2016).

Table (3): Effect of using different solvents on total polyphenol contents extracted from agro-industrial by-products.

\begin{tabular}{|c|c|c|c|c|}
\hline \multirow{2}{*}{$\begin{array}{c}\text { Extraction } \\
\text { solvent }\end{array}$} & \multicolumn{4}{|c|}{ Total polyphenols (mg Tannic acid/g of dry weight) } \\
\cline { 2 - 5 } & mango seed & mango peel & Onion skin & black rice bran \\
\hline Ethanol & $6.18^{\mathrm{b}}$ & $4.91^{\mathrm{b}}$ & $4.63^{\mathrm{b}}$ & $6.38^{\mathrm{b}}$ \\
\hline Ethyl acetate & $4.40^{\mathrm{c}}$ & $3.70^{\mathrm{c}}$ & $2.80^{\mathrm{c}}$ & $5.30^{\mathrm{c}}$ \\
\hline Acetone & $3.30^{\mathrm{d}}$ & $3.00^{\mathrm{d}}$ & $2.30^{\mathrm{d}}$ & $3.90^{\mathrm{d}}$ \\
\hline Methanol & $6.54^{\mathrm{a}}$ & $5.40^{\mathrm{a}}$ & $5.10^{\mathrm{a}}$ & $6.80^{\mathrm{a}}$ \\
\hline LSD & $* *$ & $* *$ & $* *$ & $* *$ \\
\hline
\end{tabular}

* Each value is an average of three determinations.

+ Values followed by the same letter in Colum are not significantly different at $P \leq 0.05$. 
Improving oils stability during deep-fat frying using natural antioxidants ........

*= Significant; **= high Significant; NS= No Significant.

Table (4): Antioxidant activity assays of crude methanol extracts of agro-industrial byproducts by DPPH .

\begin{tabular}{|c|c|c|c|c|}
\hline \multirow{2}{*}{ Samples } & \multicolumn{4}{|c|}{ DPPH Scavenging (\%) } \\
\cline { 2 - 5 } & $100(\mathrm{ppm})$ & $200(\mathrm{ppm})$ & $300(\mathrm{ppm})$ & $400(\mathrm{ppm})$ \\
\hline TBHQ & $81.20^{\mathrm{a}}$ & $87.50^{\mathrm{a}}$ & $93.60^{\mathrm{a}}$ & $97.20^{\mathrm{a}}$ \\
\hline mango seed & $42.20^{\mathrm{c}}$ & $60.01^{\mathrm{d}}$ & $72.30^{\mathrm{d}}$ & $80.30^{\mathrm{c}}$ \\
\hline mango peel & $40.60^{\mathrm{d}}$ & $60.00^{\mathrm{d}}$ & $70.90^{\mathrm{c}}$ & $78.10^{\mathrm{d}}$ \\
\hline Onion skin & $41.90^{\mathrm{c}}$ & $61.50^{\mathrm{c}}$ & $73.50^{\mathrm{c}}$ & $78.19^{\mathrm{d}}$ \\
\hline black rice bran & $46.90^{\mathrm{b}}$ & $64.30^{\mathrm{b}}$ & $74.60^{\mathrm{b}}$ & $82.90^{\mathrm{b}}$ \\
\hline LSD & $* *$ & $* *$ & $* *$ & $* *$ \\
\hline
\end{tabular}

Each value is an average of three determinations.

Values followed by the same letter in columns are not significantly different at $P<0.05$.

*= Significant; **= high Significant; NS= No Significant.

Identification of polyphenolic compound of agro-industrial byproducts methanol extracts.

The aforementioned set of experiments relevant to the antioxidant efficiency of the total polyphenols extracts of agro-industrial by-products (mango seed kernel, mango peel, onion skin and black rice bran) and demonstrated that the total polyphenols compounds possessed remarkable antioxidant activity. Therefore, it is quite necessary to characterize the phenolic compounds of total polyphenols extracts. High performance liquid chromatography (HPLC) was used for the qualitative and quantitative determination of total polyphenols. Table (5) indicated that, Salicylic, Chtechin and Protocatechuic acids (60.7, 51.7 and $46.1 \mathrm{mg} / 100 \mathrm{~g}$ respectively) were the major phenolic compounds presented and identified in Mango seed kernel. In addition, Salicylic, EL lagalic and mangifern acids (74.9, 47.3 , and $42.7 \mathrm{mg} / 100 \mathrm{~g}$ respectively) were the major phenolic compounds presented and identified in Mango peel. while, Benzoic, Caffeic and Catechol acids (46.8, 40.1, and $39.4 \mathrm{mg} / 100 \mathrm{~g}$ respectively) were the major phenolic compounds presented and identified in Onion skein. Ferulic, p-coumaric and Caffeic acids (164.3, 32.1, and 25.4 $\mathrm{mg} / 100 \mathrm{~g}$ respectively) were the major phenolic compounds presented and identified in black rice bran These result agree with Salem et al. (2018).

\section{Antioxidant activity of phenolic compounds:}

Effect of antioxidant activity for phenolic compounds extracted from agro-industrial by-products on blend oils (mixture with sunflour and soyabean oils) is shown in Table (6). The effect of various concentrations of phenolic compounds extracted from agroindustrial by-products and TBHQ at 200 ppm as antioxidant on the development of peroxide value of blended oils during 5 days of storage at $60^{\circ} \mathrm{C}$. It is evident from these results that, a continuous increase in peroxide value of blend oil with the increasing of storage times for all the samples.

Peroxide value of blend oil without additives (control) was increased rapidly after 5 days and slowly increased in samples with 200 ppm TBHQ and 400 ppm phenolic compounds extracted from agro-industrial by-products, as the concentration of antioxidant increased the inhibitory effect on peroxide value increased. However after 5 days of storage at $60 \mathrm{C}$, peroxide value were 9.23 , 8.91 and 8.68; 9.36, 9.00 and 8.75: 9.47,9.09 and 8.86 and9.27, 8.92 and 8.66 
Sahar R. Abd El-Hady, et al.,

meq/kg-1 for blend oil treated with 100 , 200 and 400 ppm of phenolic compound extracted from, Mango seed kernel, mango peel; onion skin and black rice bran respectively. Whereas, the corresponding value were 19.10 and 9.22 meq/kg-1 at (control) without additives and $200 \mathrm{ppm}$ concentration of TBHQ respectively. On the other hand, concentration of $400 \mathrm{ppm}$ of phenolic compounds extracted from agroindustrial by-products had the same effective for retarding development of peroxide value than using $200 \mathrm{ppm}$ TBHQ. Therefore, adding natural phenolic compounds extracted from agroindustrial by-products either using 200 or $400 \mathrm{ppm}$ as antioxidant with blend oil were more effective for decreasing the development of blend oils oxidation than using $100 \mathrm{ppm}$ as antioxidant. Our results may be due to the antioxidant activity of phenolic compounds is mainly due to their redox properties, which can play an important role in adsorbing and neutralizing free radicals, quenching singlet triplet oxygen, or decomposing peroxides (Zheng and Wang 2001).

Effect of using methanolic extracts from agro-industrial by-products on peroxide value (PV) of blend oil:

The data presented in Table (7) illustrate that, peroxide value (PV) of blend oil was increased by increasing the frying hours. On the other hand, PV for oils treated by mango seed kernel, mango peel, onion skin, black rice bran phenolic extracts at 400 ppm concentration, TBHQ at $200 \mathrm{ppm}$ concentration and control were increased to $19.20,19.40,19.80,19.00,20.10$ and $26.00 \mathrm{meq} / \mathrm{kg}$ oil after 25 hours of frying, respectively.

Table (5): Identification of polyphenolic compounds of mango seed kernel, mango peel, onion skein and black rice bran $(\mathrm{mg} / 100 \mathrm{~g})$.

\begin{tabular}{|l|c|c|c|c|}
\hline $\begin{array}{l}\text { Phenolic compounds } \\
\text { contents }\end{array}$ & $\begin{array}{c}\text { Mango seed } \\
\text { kernel }\end{array}$ & $\begin{array}{c}\text { Mango } \\
\text { peel }\end{array}$ & $\begin{array}{c}\text { Onion } \\
\text { skein }\end{array}$ & $\begin{array}{c}\text { Black rice } \\
\text { bran }\end{array}$ \\
\hline Gallic acid & 23.80 & 7.4 & 4.7 & 0 \\
\hline Ferulic acid & 0.35 & 13.2 & 2.35 & 164.3 \\
\hline Chtechin acid & 51.7 & 20.8 & 5.4 & 5.0 \\
\hline Protocatechuic acid & 46.1 & - & 13.6 & 2.3 \\
\hline Cinnammic acid & - & 17.6 & - & - \\
\hline mangifern & 11.0 & 42.7 & - & - \\
\hline Benzoic acid & 23.0 & - & 46.8 & - \\
\hline Catechol acid & - & - & 39.4 & 0 \\
\hline Caffien acid & - & 11.6 & 27.1 & 22.9 \\
\hline EL lagalic acid & 6.4 & 47.3 & - & - \\
\hline p-coumaric Acid & - & - & - & 32.1 \\
\hline Vanilic acid & 23.6 & 21.0 & 3.8 & 11.6 \\
\hline Caffeic acid & - & 8.2 & 40.1 & 25.4 \\
\hline Chlorogenic acid & 18.5 & - & 7.9 & 1.84 \\
\hline Syringic acid & - & - & - & 0.91 \\
\hline Salicylic acid & 60.7 & 74.9 & 17.1 & - \\
\hline Chrysin & - & - & - & 0.67 \\
\hline
\end{tabular}


Improving oils stability during deep-fat frying using natural antioxidants .....

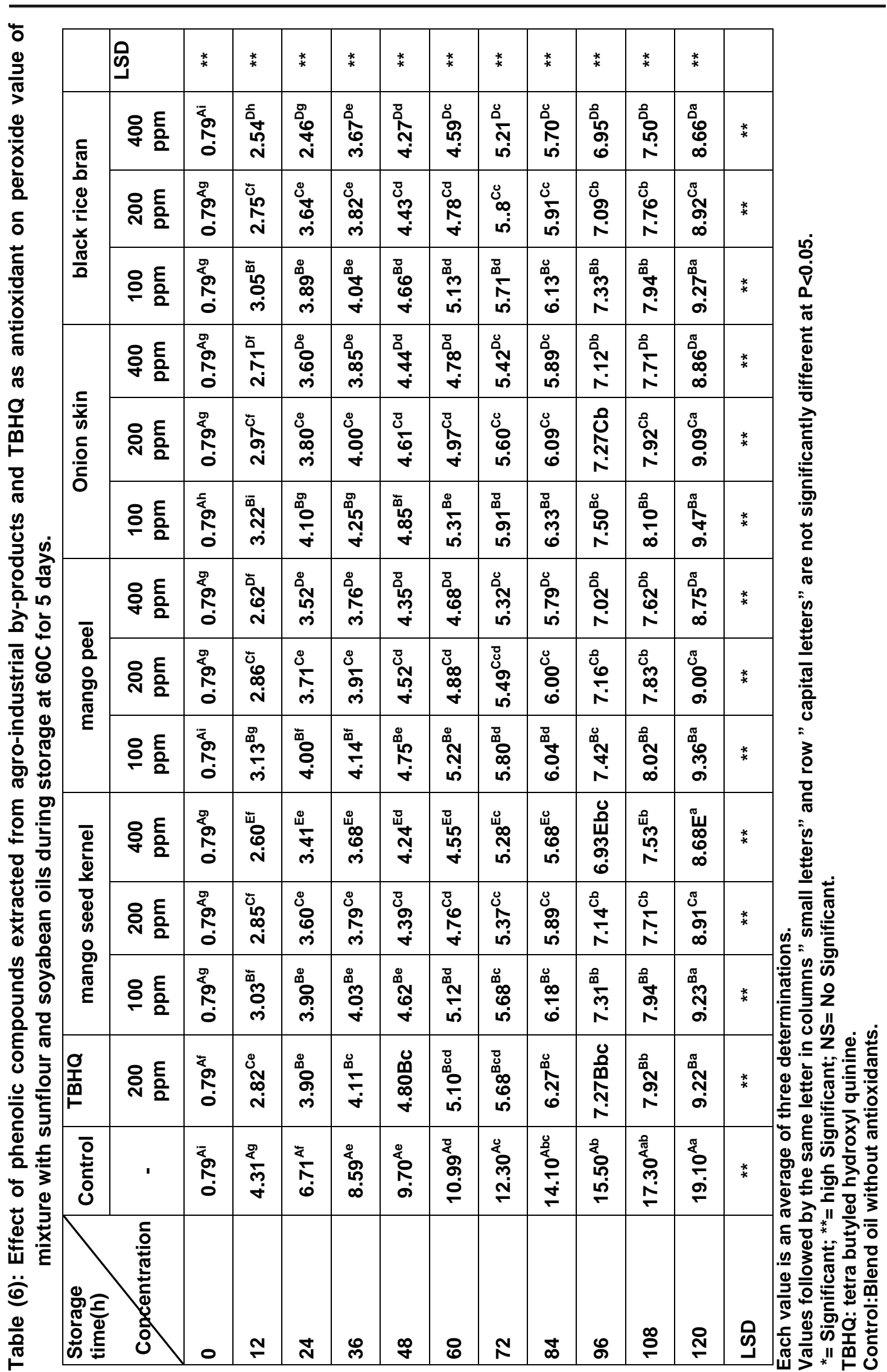


Sahar R. Abd El-Hady, et al.,

Table (7): Effect of polyphenolic extracts and TBHQ on peroxide value (PV) during the deep frying of blend oil.

\begin{tabular}{|c|c|c|c|c|c|c|c|}
\hline \multirow{3}{*}{$\begin{array}{l}\text { Treatments } \\
\text { Frying time } \\
\text { (hr) }\end{array}$} & \multirow{2}{*}{ Control } & \multirow{2}{*}{$\begin{array}{c}\text { TBHQ } \\
(200 \mathrm{ppm})\end{array}$} & \multicolumn{4}{|c|}{$\begin{array}{l}\text { Antioxidant extracted from agro- } \\
\text { industrial by-products at } 400 \text { ppm conc. }\end{array}$} & \\
\hline & & & $\begin{array}{c}\text { mango } \\
\text { seed } \\
\text { kernel }\end{array}$ & $\begin{array}{l}\text { Mango } \\
\text { peel }\end{array}$ & $\begin{array}{l}\text { Onion } \\
\text { skin }\end{array}$ & $\begin{array}{c}\text { black } \\
\text { rice } \\
\text { bran } \\
\end{array}$ & \\
\hline & \multicolumn{6}{|c|}{ Peroxide value (meq/kg oil) } & \\
\hline 0 & $5.80^{A f}$ & $5.80^{\mathrm{Af}}$ & $5.80^{\mathrm{Af}}$ & $5.80^{\mathrm{Af}}$ & $5.80^{\mathrm{Af}}$ & $5.80^{\mathrm{Af}}$ & - \\
\hline 5 & $12.10^{\mathrm{Ae}}$ & $8.60^{\mathrm{Be}}$ & $8.40^{\mathrm{Be}}$ & $8.30^{\mathrm{Be}}$ & $8.55^{\mathrm{Be}}$ & $8.40^{B d}$ & * \\
\hline 10 & $15.30^{\mathrm{Ad}}$ & $9.40^{\mathrm{Bd}}$ & $9.50^{\mathrm{Bd}}$ & $9.40^{\mathrm{Bd}}$ & $9.80^{\mathrm{Bd}}$ & $9.00^{\mathrm{Bc}}$ & * \\
\hline 15 & $18.10^{\mathrm{AC}}$ & $12.11^{\mathrm{Bc}}$ & $11.40^{\mathrm{Cc}}$ & $11.70^{\mathrm{Cc}}$ & $12.00^{\mathrm{BC}}$ & $11.00^{\mathrm{Dc}}$ & * \\
\hline 20 & $19.20^{\mathrm{Ab}}$ & $16.30^{\mathrm{B} \mathrm{b}}$ & $15.80^{\mathrm{Bb}}$ & $15.70^{\mathrm{B} \mathrm{b}}$ & $16.00^{\mathrm{Bb}}$ & $15.50^{\mathrm{Bb}}$ & * \\
\hline \multirow[t]{2}{*}{25} & $26.00^{\mathrm{Aa}}$ & $20.10^{\mathrm{Ba}}$ & $19.20^{\mathrm{Ba}}$ & $19.40^{\mathrm{Ba}}$ & $19.80^{\mathrm{Ba}}$ & $19.00^{\mathrm{Ba}}$ & * \\
\hline & ** & ** & ** & ** & ** & ** & LSD \\
\hline
\end{tabular}

Each value is an average of three determinations.

Values followed by the same letter in columns " small letters" and row " capital letters" are not significantly different at $\mathrm{P}<0.05$.

*= Significant; **= high Significant; NS= No Significant.

TBHQ: tetra butyled hydroxyl quinine.

Control: Blend oil without antioxidants.

Black rice bran phenolic extract had the highest activity in increasing the thermal oxidation. These results are consistent with findings of Upadhyay, et al. (2017) and Salem et al. (2018), who reported that lipid peroxides were significantly reduced by the addition of antioxidants in thermal processed oil.

Effect of using methanolic extracts from agro-industrial by-products on Thiobarbituric acid (TBA) of blend oil:

There are two stages of oil oxidation, i.e., the first stage is the formation of hydro peroxides and the second one is the decomposition of hydroperoxides to produce secondary oxidation products which could be react with TBA reagent to produce coloured compounds (Orthoefer et al., 1996). Thiobarbituric acid (TBA) of fresh and fried blend oil was determined and the results are presented in Table (8). The rates of TBA values were rapidly increased with increasing the frying period compared to control.

Compared to heated control $(8.0 \mathrm{mg}$ malonaldhyde/kg oil) for 25 frying hours. All antioxidant extracts and TBHQ decreased the TBA value to $3.20,3.30$, $3.50,3.0$ and $3.60 \mathrm{mg}$ malonaldhyde $/ \mathrm{kg}$ oil, for mango seed kernel, mango peel, onion skin, black rice bran phenolic extracts at $400 \mathrm{ppm}$ and TBHQ at 200 ppm respectively. Generally, Table (8) also cleared that, black rice bran extract was more effective as antioxidant than those of the other studied by-products and TBHQ. Similar results were obtained by Devi et al. (2007) who showed that, the rice bran (RB) extracts were stable at high temperatures and therefore capable 
of protecting soybean oil against

oxidation even at elevated temperatures.

Table (8): Effect of polyphenolic extracts and TBHQ on thiobarbituric acid (T.B.A) during the deep frying of blend oil.

\begin{tabular}{|c|c|c|c|c|c|c|c|}
\hline \multirow{3}{*}{$\begin{array}{l}\text { Treatments } \\
\text { Frying } \\
\text { time (hr) }\end{array}$} & \multirow[t]{2}{*}{ Control } & \multirow{2}{*}{$\begin{array}{l}\text { TBHQ } \\
(200 \\
\text { ppm) }\end{array}$} & \multicolumn{4}{|c|}{$\begin{array}{l}\text { Antioxidant extracted from agro-industrial } \\
\text { by-products at } 400 \mathrm{ppm} \text { conc. }\end{array}$} & \\
\hline & & & $\begin{array}{c}\text { mango } \\
\text { seed } \\
\text { kernel }\end{array}$ & $\begin{array}{c}\text { Mango } \\
\text { peel }\end{array}$ & $\begin{array}{l}\text { Onion } \\
\text { skin }\end{array}$ & $\begin{array}{l}\text { black } \\
\text { rice } \\
\text { bran }\end{array}$ & \\
\hline & \multicolumn{7}{|c|}{ TBA (mg malonaldhyde/kg oil) } \\
\hline 0 & $0.70^{\mathrm{Ae}}$ & $0.70^{\mathrm{Ad}}$ & 0.70 Ad & $0.70^{\mathrm{Ad}}$ & $0.70^{\mathrm{Ad}}$ & $0.70^{A C}$ & \\
\hline 5 & $1.87^{\mathrm{Ad}}$ & $0.63^{\mathrm{Bd}}$ & $0.61^{\mathrm{Bd}}$ & $0.61^{\mathrm{Bd}}$ & $0.63^{\mathrm{Bd}}$ & $0.64^{\mathrm{BC}}$ & * \\
\hline 10 & $2.82^{A C}$ & $0.78^{\mathrm{Bd}}$ & $0.71^{\mathrm{Bd}}$ & $0.78^{\mathrm{Bd}}$ & $0.74^{\mathrm{Bd}}$ & $0.73^{\mathrm{BC}}$ & * \\
\hline 15 & $3.87^{\mathrm{Ab}}$ & $1.64^{\mathrm{BC}}$ & $1.58^{\mathrm{BC}}$ & $1.63^{\mathrm{BC}}$ & $1.64^{\mathrm{BC}}$ & $1.60^{\mathrm{Bb}}$ & * \\
\hline 20 & $7.85^{\mathrm{Aa}}$ & $3.00^{\mathrm{Bb}}$ & $2.83^{\mathrm{Bb}}$ & $2.90^{\mathrm{Bb}}$ & $2.90^{\mathrm{BD}}$ & $2.85^{\mathrm{Ba}}$ & * \\
\hline \multirow[t]{2}{*}{25} & $8.00^{\mathrm{Aa}}$ & $3.60^{\mathrm{Ba}}$ & $3.20^{\mathrm{Ba}}$ & $3.30^{\mathrm{Ba}}$ & $3.50^{\mathrm{Ba}}$ & $3.00^{\mathrm{Ba}}$ & * \\
\hline & ** & ** & ** & ** & ** & ** & LSD \\
\hline
\end{tabular}

Each value is an average of three determinations.

Values followed by the same letter in columns " small letters" and row " capital letters" are not significantly different at $\mathrm{P}<0.05$.

*= Significant; **= high Significant; NS= No Significant.

TBHQ: tetra butyled hydroxyl quinine.

Control Blend oil without antioxidants.

\section{CONCLUSION}

From the previous results, it could be concluded that, the antioxidative activity of black rice bran methanolic extracts was greater than those of Mango seed kernel, mango peel and onion skin. The use of methanolic extracted from agroindustrial by-products could be added at levels of $400 \mathrm{ppm}$ to increase the heat stability of oils and in the same time possessed no hazard effect on human being health.

\section{REFERENCES}

A.O.A.C. (2005). Association of Official of Analytical Chemists, Official Methods of Analysis. 18th Ed., Pub. By the A.O.A.C., Arlington, Virginia, 2220 USA.

Abbasi, A.M., X. Guo, X. Fu, L. Zhou, Y. Chen, Y. Zhu, H. Yan and R.H. Liu (2015). Comparative Assessment of Phenolic Content and in Vitro Antioxidant Capacity in the Pulp and
Peel of Mango Cultivars. Int. J. Mol. Sci. 2015, 16: 13507-13527.

Abdalla, A. E. M., S. M. Darwish, E. H. E. Ayad and R.M. El-Hamahmy (2007a). Egyptian mango by-product 1: Compositional quality of mango seed kernel. Food Chemistry, 103: 11341140.

Abdalla, A. E. M., S. M. Darwish, E. H. E. Ayad and R.M. El-Hamahmy (2007b). Egyptian mango by-product 2: Antioxidant and antimicrobial activities of extract and oil from mango seed kernel. Food Chemistry, 103: 1141-1152.

Abdel, M., I. Ashoush and Nessrien M. (2012). Characteristics of mango seed kernel butter and its effects on quality attributes of muffins. Food Science and Technology, 9(2): 1-9.

Ajila, C., M. Aalami, K. Leelavathi and U. Rao (2010). Mango peel powder: A potential source of antioxidant and dietary fiber in macaroni preparations. 
Innov. Food Sci. Emerg. Tech., 11: 219-224.

Ajila, C.M., K.A. Naidu, S.G. Bhat and U.J.S. Prasada-Rao (2007). Bioactive compounds and antioxidant potential of mango peel extract. Food Chem 105:982-8.

Araba, F., I. Alemzadehb and V. Maghsoudib (2011). Determination of antioxidant component and activity of rice bran extract. Chemistry and Chemical Engineering, $4: 120$-128.

Azza, M. Abdel-Aty, Walaa H. Salama, M.B. Hamed, Afaf S. Fahmy and S.A. Mohamed (2018). Phenolicantioxidant capacity of mango seed kernels: therapeutic effect against viper venoms Revista Brasileira de Farmacognosia, 28 :594-601.

Bonoli, M., V. Verardo, E. Marconi and M. F. Caboni (2004). Antioxidant phenols in barley (Hordeum vulgare L.) flour: comparative spectrophotometric study among extraction methods of free and bound phenolic compounds. Journal of Agricultural and Food Chemistry, 52: 5195-5200.

Devi, R. R., A. J. Jayalekshmy and C. Arumughan (2007). Antioxidant efficacy of phytochemical extracts from defatted rice bran in the bulk oil system. Food Chem., 104: 658-664.

Einbond, L.S., K.A. Reynertson, X-D. Luo, M.J. Basile and E.J. Kennelly (2004). Anthocyanin antioxidants from edible fruits. Food Chemistry, 84: 23-28.

El Anany, A.M. (2007). Influence of pomegranate (Punica granatum) peel extract on the stability of sunflower oil during deep-fat frying process. Electron. J. Food Plants Chem., 2: 1419.

El-Faham, S. Y., M. S. Mohsen, A. M. Sharaf and A. A. Zaky (2016). Utilization of Mango Peels as a Source of Polyphenolic Antioxidants. Current Sci. International , 5 ( 4 ) : 529-542.

El-hassaneen, Y., S. El-Waseef, Naglaa N. Fathy and S. Ahmed (2016). Bioactive
Compounds and Antioxidant Potential of Food Industry By-products in Egypt. American Journal of Food and Nutrition, 4 (1): 1-7.

Elizabeth, A., R. PletschBruce and Hamaker (2017). Brown rice compared to white rice slows gastric emptying in humans. European J. of Clinical Nutr., 1;22(6): 971-82.

Erwin, W., G. Anna, H. Marzanna, H.J. Henryk, K. Jozef, M. Maria, M. Sylwia, R. Magdalena, S. Urszula and $Z$. Renata (2004). Oxidation of lipids in food. Pol. J. Food Nutr. Sci., 13: 87100.

Evangelisli, F., Zunin, P., E. Tisconia, R. Petacchi, G. Drava and S. Lanteri (1997). Stability to oxidation of virgin olive oils as related to olive conditions: Study of polar compounds by chemometric methods. J. of Am. Oil. Chem. Soc., 74(8): 10 17-1022.

Gawlik-Dziki, M. S., B. A. Dariusz-Dziki, T. Justyna and C. Jarosław (2013). Quality and antioxidant properties of breads enriched with dry onion (Allium cepa L.) skin. Food Chemistry, 138: 1621-1628.

Gertz, C., S. Klostermann and P. S. Kochhar (2000). Testing and comparing stability of vegetable oils and fats at frying temperature. Eur. J. Lipid Sci. Technol. 102: 543-551.

Gonzalez, M. and V. Gonzalez (2010) . Sample preparation of tropical and subtropical fruit biowastes to determine antioxidant phytochemicals. Anal Methods 2:1842-66.

Griffiths, G., L. Trueman, T. Crowther, B. Thomas and B. Smith (2002). Onions: A global benefit to health. Phytother Res., 16: 603-615.

Gumte, S.V., A.T. Taur, A.R. Sawate and P.P. Thorat (2018). Effect of processing on proximate and phytochemical content of mango (Mangifera indica) kernel. International 
Journal of Chemical Studies , 6(2): 3728-3733.

Hala, S. Sayed, Nahla M. M. Hassan and M.H. Abed El khalek (2014). The effect of using onion skin powder as a source of dietary fiber and antioxidants on properties of dried and fried noodles. Current Sci., International, 3(4): 468-475.

Hou, D.X. (2003). Potential mechanism of cancer chemoprevention by anthocyanin. Current Advancements in Molecular Medicines, 3: 149-159.

lqbal, S., M. I. Bhanger and F. Anwar (2005). Antioxidant properties and components of some commercially available varieties of rice bran in Pakistan. Food Chem., 93: 265-272.

Jayaprakasha, G., R. Singh and K. Sakariah (2001). Antioxidant activity of grape seed (Vitis vinifera) extracts on peroxidation models in vitro. Food Chemistry, 37: 285-290.

Kim, H., J.Y. Moon and H. Kim (2010). Antioxidant and antiproliferative activities of mango (Mangifera indica L.) flesh and peel. Food Chem., 121: 429-436.

Lafka, T.I., V. Sinanoglou and E.S. Lazos (2007). On the extraction and antioxidant activity of phenolic compounds from winery wastes. Food Chem.,104 (3):1206-14.

Lee, S.C., J.H. Kim, K.C. Nam and D.U. Ahn (2003). Antioxidant properties of far infrared-treated rice hull extract in irradiated raw and cooked turkey breast. J. Food Sci., 68: 1904-1909.

Leonard, W.A., A.E. Woods and M.K. Wells (1987). Food Composition and Analysis.Publ. by Van Nastr and Rinhold Com. New York. pp. 255-258.

Matthaus, B. (2002). Antioxidant activity of extracts obtained from residues of different oil seeds. J. Agric. Food Chem., 47:2350-2354

Manthey, J. A. and P. Perkins-Veazie (2009). Influences of harvest date and location on the levels of $\beta$-carotene, ascorbic acid, total phenols, the in vitro antioxidant capacity, and phenolic profiles in five commercial varieties of mango (Mangifera indica L.). J. Agric. Food Chem. 57: 1082510830.

Mohdaly, A., M. A. Sarhan, I. Smetanska and A. Mahmoud (2010). Antioxidant properties of various solvent extracts of potato peels, sugar beet pulp, and sesame cake. J. of the Sci. of Food and Agric., 90: 218-226.

Mostafa, U.E. (2013). Phenolic Compounds and antioxidant potential of mango peels and kernels (Mangifera indica L.) on the frying oil stability, lipid profile and activity of some antioxidant serum enzymes in rats .J. of American Sci., 9 (11): 371378.

Nordin, N.N.A.M., R. Karim, H.M. Ghazali, N.M. Adzahan and M.T. Sultan (2014). Effects of various stabilization techniqueson the nutritional quality and antioxidant potential of brewer's rice. J. Eng. Sci. Technol., 9: 347-363.

Orthpoefer, F.T. (1996). Rice Bran Oil: Healthy lipid Source. Food Tech. December: 62-64.

Pitchaporn, W., K. Niwat and N. S. Sirithon (2016). Bioactive compounds and antioxidant properties of different solvent extracts derived from Thai rice by-products. Appl. Biol. Chem., 59 (3): 373-384

QD, D.O., A.E. Angkawijaya, P.L. TranNguyen, L.H. Huynh, F.E. Soetaredjo and J.I. Ismad (2014). Effect of extraction solvent on total phenol content, total flavonoid content, and antioxidant activity of Limnophila aromatica. J. of food and drug analysis, 22 (3): 296-302.

Saad, B., Y.S. Yong, A.N. Mohd, H. Noorhasani, S.M.A. Abdussalam, I.S. Muhammad, F.S. Saida, M.T. Khariuddin and A. Kamarudzaman (2007). Determination of synthetic phenolic antioxidants in food items 
using reversed-phase HPLC. Food Chem. 105: 389-394.

Salem, M. A., A. M. Sorour and M.A. EIBana (2018). Potential antioxidative. Activity of rice milling by-products. Menoufia J. Food and Dairy Sci., 3: 113.

Scalbert, A., I.T. Johnson and M. Saltmarsh (2005). Polyphenols: antioxidants and beyond. Am. J. of Clin. Nutr., 81: 215-217.

Sidwell, C. G., H. Saiwin, M. Benca and J.H. Mitechell (1990). The use of thiobarbituric acid as a measure of fat oxidation. Am. of Oil Chem. Soci., 3(12): 603-606.

Steell, R.G. and J.H. Torrie (1980). Principles and procedures of statistics.2nd Ed. pp 120. McGraw-Hill, New York, USA.

Su, C. S. and Y. P. Chen (2007). Correlation for the Solubilities of Pharmaceutical Compounds in Supercritical Carbon Dioxide. Fluid Phase Equilibria 254(1-2): 167-173.

Sultana, B., F. Anwar and R. Przybylski (2007). Antioxidant potential of corncob extracts for stabilization of corn oil subjected to microwave heating. Food Chem., 104: 997-1005 .

Upadhyay, R., S. Sehwag and Niwas H. Mishra (2017). Chemometric approach to develop frying stable sunflower oil blends with oleoresin rosemary and ascorbyl palmitate. Food Chem, 218: 496-504.

Viera, V.B., N. Piovesan, J.B. Rodrigues, R. de O. Mello, R.C. Prestes, R.C. V dos. Santos, R. D. A. Vaucher, T. P. Hautrive and E. H. Kubota (2017). Extraction of phenolic compounds and evaluation of the antioxidant and antimicrobial capacity of red onion skin (Allium cepa L.). International Food Res. J., 24 (3): 990-999.

Walter, M. and E. Marchesan (2011). Phenolic compounds and antioxidant activity of rice. Braz. arch. biol. technol., 54 ( 2 ) Curitiba Mar.IApr.

Yanishlieva, N.V. and E.M. Marinova (2001). Stabilization of edible oils with natural antioxidants. European J. of Lipid Sci. and Tech., 103.

Yao, Y., W. Sang, M. Zhou and G. Ren (2010). Antioxidant and a-glucosidase inhibitory activity of colored grains in China. J. of Agri. and Food Chem., 58: 770-774.

Yawadio, R., S. Tanimori and N. Morita (2007). Identification of phenolic compounds isolated from pigmented rices and their aldose reductase inhibitory activities. Food Chem, 101: 1616-1625.

Zheng, W. and S. Y. Wang (2001). Antioxidant activity and phenolic compounds in selected herbs. $J$. Agric. Food Chem., 49: 5165-5170. 
تحسين ثبات الزيوت أثناء القلي العميق باستخدام مضادات الأكسدة الطبيعية

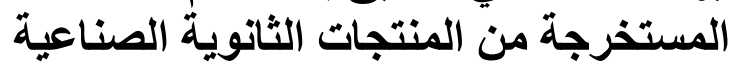

سحر رمضان عبدالهادى(1) ، يسرى شهاب(2) ، عواطف ايراهيم اسماعيل(2) ،

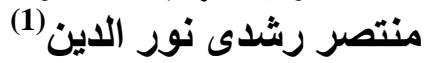

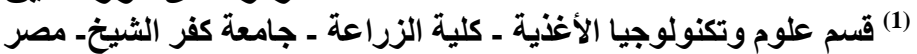

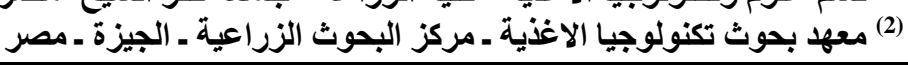

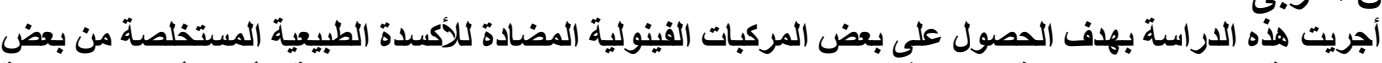

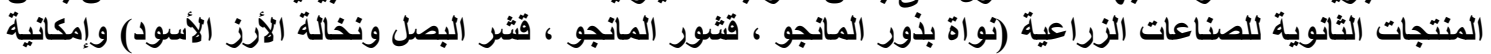

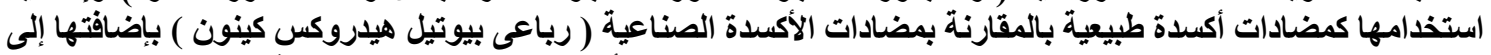

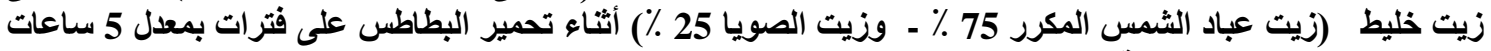

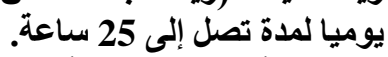

وقد أظهرت النتائج أن الميثانول كان أفضل مذيب لاستخلاص المواد المضادة للأكسدة .و كانت المركبات الفينولية

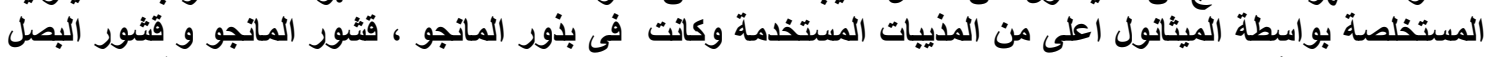

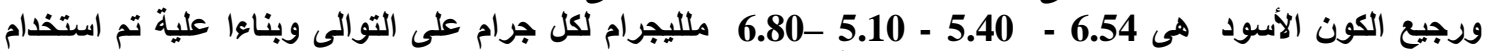

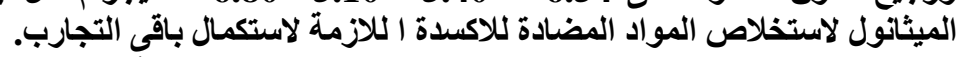

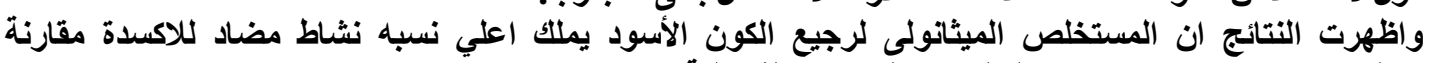

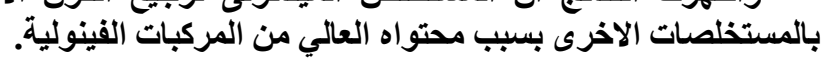

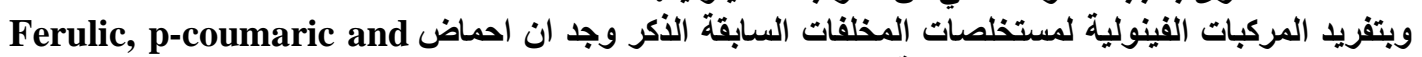

Caffeic acids

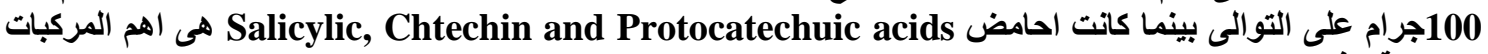

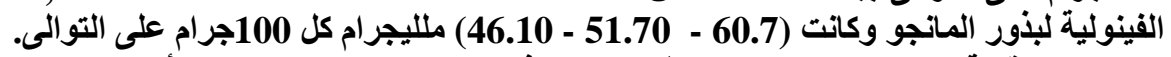

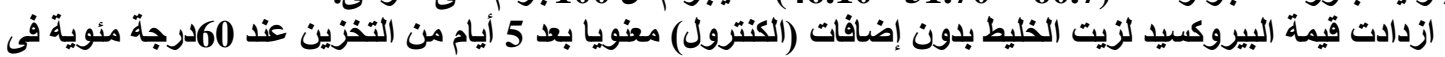

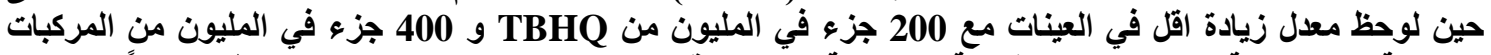

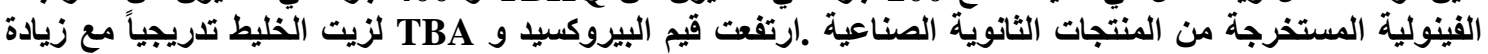

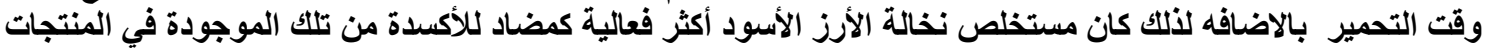

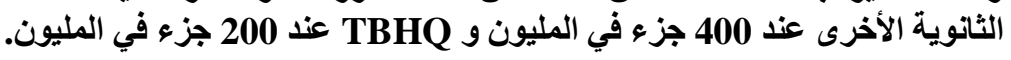

